\title{
Meet the 2016 APSA Ralph Bunche Summer Institute Scholars
}

$\mathrm{N}$ amed in honor of the 1950 Nobel Peace Prize winner and former APSA President, Ralph J. Bunche, the Ralph Bunche Summer Institute (RBSI) encourages students to pursue academic careers in political science by (1) enhancing writing, research, and analytical skills to increase competitiveness in the application and financial aid process for graduate school; (2) developing statistical skills for data analysis used in political science; (3) exposing participants to the significant questions in the discipline and profession of political science; (4) introducing participants to leading political scientists; (5) educating participants about political science career opportunities; and (6) encouraging their application to doctoral programs in political science.

The RBSI is an intensive five-week program held at Duke University. It is designed to introduce to the world of doctoral study in political science those undergraduate students from under-represented racial and ethnic groups or those interested in broadening participation in political science and pursuing scholarship on issues affecting underrepresented groups. Participants in the RBSI are drawn from a competitive national applicant pool. The RBSI Selection Committee reviews applications and makes decisions each year. This marks the zoth anniversary of the RBSI Program. APSA is happy to announce the 2016 RBSI Scholars, and we look forward to another successful 30 years.

\section{DARA GAINES}

Dara Gaines is an honors junior majoring in political science at The University of Arkansas. She is the vice president of the Lambda Theta Chapter of Delta Sigma Theta Sorority, Inc. She is also a Silas H. Hunt and Dean's List scholar, president of the Black Student's Association and vice president of the Black Alumni Association. Dara was recently selected as the undergraduate recipient of the Northwest Arkansas Democratic Black

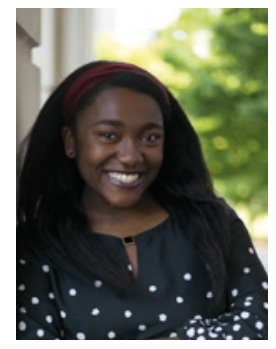
Caucus Emerging Leader Scholarship. Due to her passion for history and working with children, Dara has developed an interest in the political participation habits of Black youth. Exploring various ways to stimulate their interest, Dara hopes her research will help to increase their participation, even to the point of holding office themselves. After college, Dara will enroll in a political science graduate program focusing on public policy.

\section{JOSE GOMEZ}

Jose Gomez is a junior studying at Binghamton University. Throughout his college years, Jose has volunteered as a teaching assistant at Binghamton's American Civic Association and also involved himself as a graphic designer in the city of Binghamton's local elections. As a McNair Scholar, he has involved himself in multiple independent studies across multiple disciplines. Jose is passionate about research and the process of discovery. Majoring in political science, he is interested in studying issues of representation including public opinion, money in politics, and voter disenfranchisement. Jose hopes to pursue a $\mathrm{PhD}$ in American government at a top research institution.

\section{CLAUDIA GRANILLO}

Claudia Granillo is a junior at the University of Nebraska in Omaha (UNO). She is a political science major with a concentration in foreign and national security affairs and a minor in history. Claudia is a 2013 Susan T. Buffett Scholarship recipient. Her interests include questions regarding the recruitment of young women into ter-

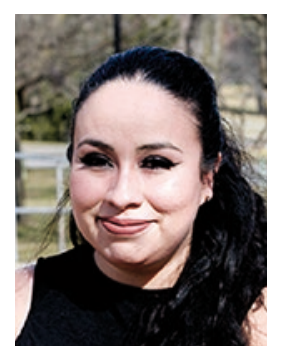
rorist organizations, the effects of US foreign policy, and the role that gender and ethnicity plays in political participation within the United States. Claudia has been accepted into the $4+1$ Political Science Program at UNO. This program will allow her to pursue her MS in political science while she is still completing her undergraduate degree. During her free time Claudia enjoys volunteering at St. Peter and Paul Catholic School.

\section{NICAURIS HEREDIA ROSARIO}

As a first-generation Latina college student, Nicauris Heredia Rosario is a junior double-major in political science and public administration at Rhode Island College.

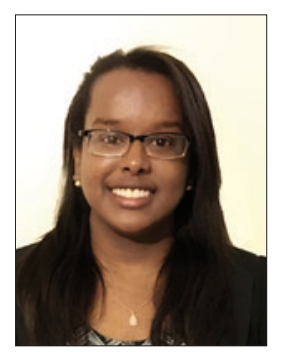

She currently serves as the president of Pi Sigma Alpha at Rhode Island College, and is the research assistant for Robyn Linde. She is also actively involved in the Political Science Club and Student Community Government. Her research interests revolve around issues of race and ethnicity in the global south, Latino political participation, human rights, immigration, and international relations. Her current honors thesis/research seeks to explain how the government of the Dominican Republic is reconstructing race in order to deny citizenship to Haitians. Upon graduating from college, Nicauris plans to enter into a political science graduate program in the field of international relations.

\section{JASMINE C. JACKSON}

Jasmine C. Jackson is a rising senior political science major at Jackson State University. A Dean's List scholar, her research interests focuses on controversial political issues that plague minority communities and the effect these issues have on societal placement. Last summer, Jasmine had the privilege of working with Geoff Ward at the University of California at Irvine on a

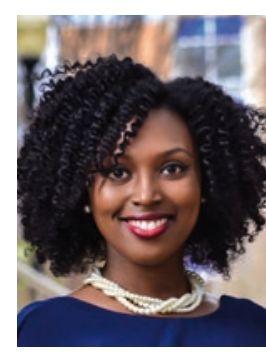
research that examines historical racial violence. She has vast research experience and has presented at the various conferences, such as the Pi Sigma Alpha Student conference, 
the Southern Political Science Association conference in Puerto Rico, and the University of Michigan's Emerging Scholars Conference. In the future, she hopes to earn a doctoral degree in political science and teach on the collegiate level.

\section{ANA JONES}

Ana Jones is a native of Shelby, North Carolina, and is currently a junior at North Carolina Central University majoring in political science. She is an advocate for racial equality and social justice and enjoys learning how state and local policies affect the lives of those she is closest to. She hopes to attend graduate school in political science to further her interest in political psychology and

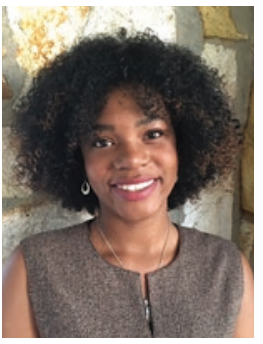
to begin her research on the psyche of the black community in the arena of politics. She also hopes to become a promoter of political education and reform in her local community.

\section{HEIDI OBEDIENTE}

Heidi Obediente is a third-year undergraduate student at the University of Central Florida (UCF). She obtained her associates degree a semester after finishing high school, and is now pursuing a BA in international and global studies, minor in cognitive sciences, and certificate in intelligence and security. Heidi is an active member of Pi Sigma Alpha, Golden Key Honor Society, the National

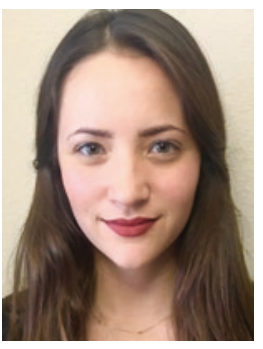
Honor Society of Leadership and Success, Tau Sigma, and three campus organizations. Heidi is active in volunteer work, including the Boys and Girls Club, the Invictus games, UNICEF, Women's Day, and the Childhood Cancer Foundation. Before graduating she will spend a semester studying at the University of Groningen and will conduct original independent research through UCF's Honors in the Major program. After completing her undergraduate studies, she intends to pursue a doctoral degree in political science with an emphasis on social policy. Her research interests include gender politics, equality rights, and global environmental sustainability.

\section{RENZO OLIVARI}

Renzo Olivari is a junior at James Madison University, graduating in May 2017. $\mathrm{He}$ is a double major in political science and history, with a minor in political communications. In the 2015-2016 academic year, he was a fellow for the Center for the Study of the Presidency and Congress, where he researched minorities' representation in Congress. $\mathrm{He}$ also has worked

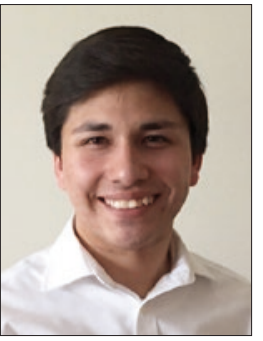
for numerous political campaigns, following his interests in voter mobilization. His research interests include minorities' interactions with the political system, as well as campaigning tactics and voter turnout. He plans on attending graduate school to study political science.

\section{DANIELLE RUSSELL}

Danielle Russell is a third-year student at the University of Connecticut and majors in political science. Recently, Danielle has been conducting research on black conservatives, their experiences, and how they are received in the black community. Her research interests include cultural diversity and race relations within the

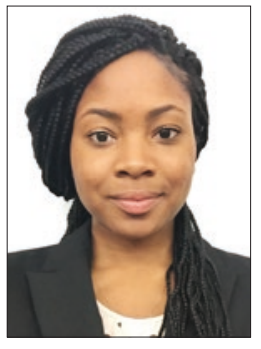
United States. After graduating, Danielle plans to pursue a $\mathrm{PhD}$ in political science and teach at the collegiate level.

\section{PRISCILLA TORRES}

With a passion for social justice and interdisciplinary education, Priscilla Torres is a political science major, biology minor, and McNair scholar at Loyola Marymount University. She has an interest in international relations that was sparked after a trip to Japan through the

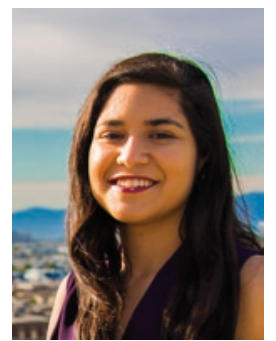
Tomodachi Inouye Scholars Program, which seeks to foster American-Japanese relations through student-to-student diplomacy.
During the fall of 2015, she completed a congressional internship in Washington, DC, participating in legislative research as a Keith Sherin Global Scholar. This past spring she received funding to take part in an international security course and conduct fieldwork in Northern Ireland focused on the importance of women in the peacebuilding process. After graduation, Priscilla hopes to pursue a $\mathrm{PhD}$ in political science to study topics of peace and conflict, and US foreign policy, hoping to become a professor to inspire a search for a deeper understanding of the world within future generations of political scientists.

\section{AKUA YAMOAH}

Akua Yamoah is a first-generation Ghanaian American born and raised in Florida. She recently graduated from the University of South Florida with two degrees in women's and gender studies and international studies. During her time in college, she became a member of Alpha Kappa Alpha Sorority, Inc. and president of Triota Honor Society her senior year. Her love

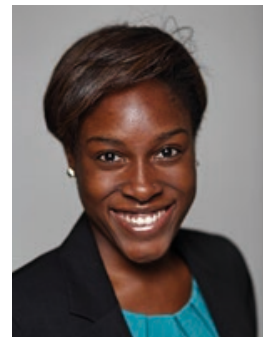
for learning about new cultures and traveling the world led her to do an internship in Washington, DC, for a semester and a summer abroad in Costa Rica. Upon graduation, she plans to give back to her country by participating in AmeriCorps then attending graduate school in fall 2017 for political science and public policy.

\section{RBSI SCHOLARS AND THEIR INSTITUTIONS}

Jeron Fenton, Princeton University

Dara D. Gaines, University of Arkansas

Jose S. Gomez, SUNY Binghamton University

Claudia Granillo, University of Nebraska in Omaha

Nicauris Heredia, Rhode Island College

Jasmine Jackson, Jackson State University

Ana Jones, North Carolina Central University

Heidi Obediente, University of Central Florida

Renzo Olivari, James Madison University

Danielle Russell, University of Connecticut

Maryam Sarhan, Stockton university

Jasmine Smith, Indiana University

Naomi Tolbert, Southern Illinois University of Carbondale

Priscilla Torres, Loyola Marymount University

Akua Yamoah, University of South Florida

Read about the 2016 RBSI Class online at http://www. apsanet.org/www.apsanet.org/rbsi2o16. 